\title{
Quantitation of Urinary Growth Hormone in Children with Normal and Abnormal Growth
}

\author{
CHRISTINE H. ALBINI, TERESA QUATTRIN, RICHARD L. VANDLEN, AND \\ MARGARET H. MACGILLIVRAY \\ Department of Pediatrics, Children's Hospital of Buffalo and State University of New York at Buffalo School of \\ Medicine, Buffalo, New York 14222 and Genentech Inc., South San Francisco, California 94080
}

\begin{abstract}
Urinary growth hormone (GH) excretion was quantitated in 12-h overnight urine collections obtained from 31 control children, ages 3 to 17 yr (group 1); 21 children, ages 5 to $19 \mathrm{yr}$ with GH deficiency (group 2), and 30 subjects, ages 10 to $18 \mathrm{yr}$ with idiopathic growth failure and normal GH stimulation tests (group 3). The output of urinary GH was measured in one acromegalic woman. The authenticity of urinary $\mathrm{GH}, 22 \mathrm{kDa}$, was confirmed by high-performance liquid chromatography. The elution pattern of urinary GH was identical to that of biosynthetic and pituitary-derived GH. The immunoreactive profiles characterized by monoclonal immunoradiometric GH assay and standard GH radioimmunoassay were identical. The quantity of GH (mean \pm SEM per $\mathrm{kg}$ body weight) in group $1(0.27 \pm 0.02 \mathrm{ng} / \mathrm{kg})$ was significantly greater than group $2(0.08 \pm 0.02 \mathrm{ng} / \mathrm{kg})$ or group $3(0.17 \pm 0.02 \mathrm{ng} /$ $\mathrm{kg}, p<0.01$ ). Approximately $50 \%$ of the subjects in group 3 had urinary GH measurements indistinguishable from those observed in the GH-deficient population. Twelve hypopituitary patients (group 2) excreted significantly greater amounts of urinary $\mathrm{GH}$ in the first $12 \mathrm{~h}$ after $\mathrm{GH}$ administration compared to the baseline period $(0.41 \pm$ 0.07 versus $0.12 \pm 0.02 \mathrm{ng} / \mathrm{kg}, p<0.01$ ). Markedly elevated output of urinary $\mathrm{GH}(2.0 \mathrm{ng} / \mathrm{kg})$ was documented in one acromegalic patient. The data suggest that measurements of urinary GH may be a useful, simple, and noninvasive screening test for identifying patients with GH deficiency or excess. (Pediatr Res 23: 89-92, 1988)
\end{abstract}

\section{Abbreviations}

GH, growth hormone

hGH, human GH

RIA, radioimmunoassay

HPLC, high-performance liquid chromatography

NHPP, National Hormone and Pituitary Program

IRMA, immunoradiometric assay

Many studies have suggested that children with idiopathic growth failure may be misjudged to be GH sufficient because they have normal $\mathrm{GH}$ responses to standard provocative agents (1-4). In this population, the diagnosis of $\mathrm{GH}$ deficiency has been established by protocols that assess spontaneous $\mathrm{GH}$ secre-

Received July 31, 1987; accepted September 22, 1987.

Supported in part by the Ralph Hochstetter Medical Research Fund in honor of Dr. Henry C. and Bertha H. Buswell and by BRSG 507RR-05493 awarded by the Biomedical Research Support Grant Program, Division of Research Resources, National Institutes of Health.

Reprint requests Dr. Margaret H. MacGillivray, Division of Endocrinology, Children's Hospital, 219 Bryant Street, Buffalo, NY 14222. tion. One method requires serial blood sampling over $24 \mathrm{~h}$; those with low mean plasma $\mathrm{GH}$ concentrations are presumed to have $\mathrm{GH}$ neurosecretory dysfunction $(2,4)$. The other method, based on continuous blood withdrawal from an indwelling venous catheter, has identified a population with low integrated plasma concentrations of $\mathrm{GH}(3,5,6)$. Neither method is used in small infants and children because the amount of blood required exceeds the limits of safety. From a practical viewpoint, these tests are uncomfortable, costly, and require special support services. Futhermore, many children with idiopathic growth failure have values that overlap with both the control and hypopitiuitary subjects $(2-4,6)$.

Given the shortcomings of current diagnostic protocols, this study was initiated to determine if measurements of urinary $\mathrm{GH}$ excretion might aid in the diagnosis of $\mathrm{GH}$ deficiency. Prior to 1970 , attempts to quantitate $\mathrm{GH}$ in urine failed because the assays lacked sensitivity and because interfering substances led to overestimation and widely discrepant results (7-13). We used a modification of the Hanssen procedure in which urine first is dialyzed, then concentrated by lyophilization after which $\mathrm{GH}$ is measured in a double antibody RIA (13). Compared to former techniques this method gives greater specificity and sensitivity. Herein the authenticity of urine GH was confirmed by using HPLC.

The three study groups included normal statured children, children with classical GH deficiency, and children with idiopathic growth failure and normal $\mathrm{GH}$ responses to provocative tests. Urine collections from 12 of the hypopituitary subjects were evaluated before and after an injection of biosynthetic $\mathrm{GH}$. In addition urinary $\mathrm{GH}$ was measured in one acromegalic patient.

\section{MATERIALS AND METHODS}

Patients. Eighty-two children participated in this study after their parents gave written, informed consent. Age, sex, and pubertal status of the participants are shown in Table 1. The subjects were divided into the following three groups. Group 1. Thirty-one healthy children ages 3 to $17 \mathrm{yr}$ who were growing between the 5 th-95th percentile for height and weight served as controls. Nineteen were prepubertal and 12 were pubertal, Tanner stage 2-5. Group 2. Twenty-one children, ages 5 to $15 \mathrm{yr}$, with $\mathrm{GH}$ deficiency based on a peak $\mathrm{GH}$ of less than $8 \mathrm{ng} / \mathrm{ml}$ after two or more stimulation tests (insulin-induced hypoglycemia, arginine infusion, clonidine or L-dopa) were in group 2. Fourteen children were severely deficient (peak $\mathrm{GH}<4 \mathrm{ng} / \mathrm{ml}$ ) and seven were partially deficient, peak $\mathrm{GH}>4$ and $<7.9 \mathrm{ng} /$ $\mathrm{ml}$ ). Eleven were prepubertal and 10 were pubertal (Tanner stage $2-4)$. The data from the severely and partially deficient were pooled because they were not significantly different. Urinary $\mathrm{GH}$ output after an intramuscular injection of biosynthetic Escherichia coli-derived methionyl $\mathrm{GH}$ (mean dose $0.05 \pm 0.01 \mathrm{mg}$ / 
Table 1. Clinical data

\begin{tabular}{ccccc}
\hline Groups & $n$ & $\begin{array}{c}\text { Prepubertal } \\
\text { (male:female) }\end{array}$ & $\begin{array}{c}\text { Pubertal } \\
\text { (male:female) }\end{array}$ & $\begin{array}{c}\text { Age range } \\
\text { (yr) }\end{array}$ \\
\hline 1 & 31 & 19 & 12 & $3-17$ \\
& & $(11: 8)$ & $(8: 4)$ & \\
2 & 21 & 11 & 10 & $5-19$ \\
& & $(9: 2)$ & $(7: 3)$ & \\
3 & 30 & 15 & 15 & $10-18$ \\
& & $(15: 0)$ & $(13: 2)$ & \\
\hline
\end{tabular}

$\mathrm{kg}$ ) was evaluated in $12 \mathrm{GH}$-deficient children. The injections were given between 1700-1800 $\mathrm{h}$ and the urine was collected from 0 to $12 \mathrm{~h}$ after the injection. Group 3 . Thirty children, ages 10 to $18 \mathrm{yr}$, with idiopathic growth failure comprised group 3 . Their heights were greater than $-2 \mathrm{SD}$ and their growth rates were less than $4 \mathrm{~cm} / \mathrm{yr}$. Their peak GH responses were $>8 \mathrm{ng} /$ $\mathrm{ml}$ to two or more GH provocative tests. Fifteen children were prepubertal and fifteen were Tanner stage $2-4$. On acromegalic adult female provided an overnight 12-h urine for GH.

Methods. Twelve-h overnight urines $(1800-0800 \mathrm{~h})$ were collected in plastic containers and kept at $4^{\circ} \mathrm{C}$ throughout the collection period. The urine was centrifuged to remove particulate matter and stored at $-20^{\circ} \mathrm{C}$. Hanssen's procedure was modified by adding $50 \mu 1$ of $2 \%$ bovine serum albumin in 0.04 M phosphate buffer, pH 7.4 (Nutritional Biochemicals, Cleveland, $\mathrm{OH}$ ) to a $50-\mathrm{ml}$ aliquot of urine instead of $0.5 \mathrm{~g}$ of human serum albumin. The urine was dialyzed and concentrated 50fold as described by Hanssen (13).

Urine GH was measured by a standard double antibody RIA method using polyclonal GH antibody and GH standards obtained from the NHPP $(14,15)$. The intraassay and interassay coefficient variation for $\mathrm{GH}$ were 2.1 and $4.0 \%$, respectively. The lower threshold of sensitivity of the assay is $0.15 \mathrm{ng} / \mathrm{ml}$.

Recovery studies were performed by adding known amounts of standard hGH (2.5-10 ng) to 50-ml aliquots of urine from GH-deficient subjects. The samples were dialyzed, lyophilized, and assayed in the same manner described above.

HPLC studies were performed on urine concentrations from four prepubertal subjects. An aliquot of the concentrated urine was applied to a reverse phase Vydac $\mathrm{C}_{4}$ column (Hesperia, CA) equilibrated in $0.05 \%$ trifluoracetic acid containing $20 \%$ acetonitrile and developed with a gradient of $20-70 \%$ acetonitrile in $30 \mathrm{~min}$ at a flow rate of $1 \mathrm{ml} / \mathrm{min}$. Fractions of $0.5 \mathrm{ml}$ were collected, dried under vacuum in a Speed Vac (Savant Instruments, Hickville, NY) and stored at $-20^{\circ} \mathrm{C}$. The samples were reconstituted in $250-\mu \mathrm{l}$ horse serum and $100 \mu \mathrm{l}$ of the reconstituted samples were assayed for $\mathrm{GH}$ using both a double monoclonal IRMA (Hybritech, Inc. San Diego, CA) and our RIA.

Statistical analyses of the data were performed using SPSSPC+ (SPSS Inc., Chicago, IL). The Student's $t$ test (paired or unpaired as indicated) was used for comparison.

\section{RESULTS}

Recovery experiments. The recovery of exogenous GH ranged from $80-100 \%$.

Identification of urinary GH by HPLC. The HPLC profile of urinary $\mathrm{GH}$ from one prepubertal male patient is shown in Figure 1. Similar HPLC profiles were observed in the other patients. Radioimmunoassayable urinary GH utilizing an IRMA assay showed the same elution pattern as biosynthetic $\mathrm{GH}$ or pituitary-derived GH. When the HPLC fractions were assayed using a standard double antibody RIA the immunoreactive profiles were identical to those obtained with the IRMA method.

Patient studies. Urinary GH excretion was standardized for body weight and expressed as $\mathrm{ng} / \mathrm{kg} / 12 \mathrm{~h}$. $\mathrm{GH}$ excretion was also standardized in terms of body surface area $\left(\mathrm{ng} / \mathrm{m}^{2} / 12 \mathrm{~h}\right)$ as well as creatinine excretion (ng/g of creatinine). The excretion of
HPLC Profile of Urinary hGH

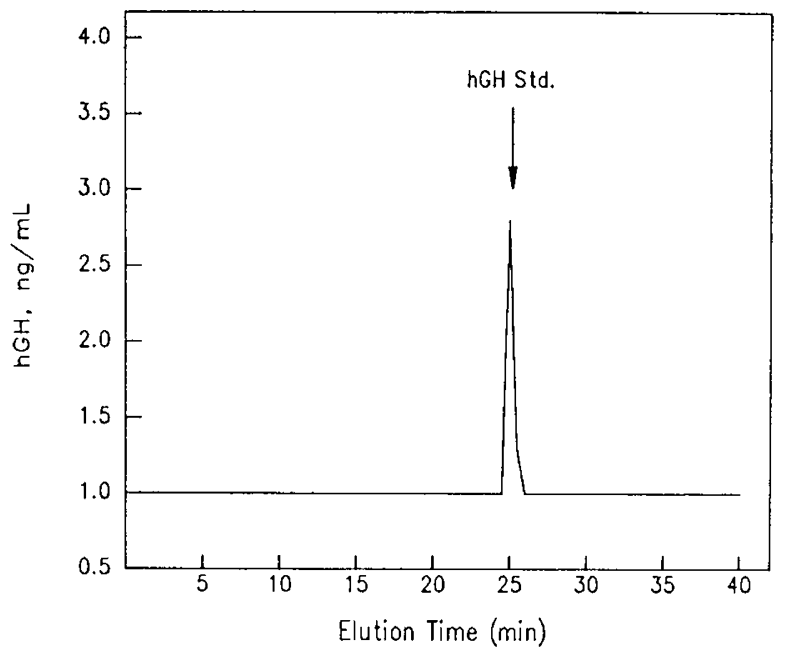

Fig. 1. HPLC elution pattern of urinary GH is identical to biosynthetic GH standard.

urinary GH (mean $\pm \mathrm{SEM}$ ) was significantly greater in group 1 $(0.27 \pm 0.02 \mathrm{ng} / \mathrm{kg} / 12 \mathrm{~h})$ than group $2(0.08 \pm 0.02 \mathrm{ng} / \mathrm{kg} / 12 \mathrm{~h})$ or group $3(0.17 \pm 0.02 \mathrm{ng} / \mathrm{kg} / 12 \mathrm{~h}, p<0.01)$ (Table 2). Children with classical GH deficiency (group 2) excrete significantly lower amounts of $\mathrm{GH}(p<0.01)$ than children with idiopathic growth failure (group 3). Individual urinary $\mathrm{GH}$ values of participants in the three groups are shown in Figure 2.

When the data were expressed in terms of body surface area $\left(\mathrm{ng} / \mathrm{m}^{2}\right)$ significantly greater output $(p<0.01)$ was also observed in children of group $1\left(7.62 \pm 0.06 \mathrm{ng} / \mathrm{m}^{2}\right)$ compared to group 2 $(2.65 \pm 0.34)$ or group $3(5.13 \pm 0.61)$. Children in group 2 excreted significantly lower amounts of $\mathrm{GH}$ than children in group $3(p<0.01)$.

Standardization of data according to creatinine excretion again showed a significantly higher output of urinary GH $(p<0.01)$ in children of group $1(43.2 \pm 6.9 \mathrm{ng} / \mathrm{g}$ of creatinine) compared to group $2(23.7 \pm 3.8 \mathrm{ng} / \mathrm{g}$ of creatinine) or group 3 (21.9 \pm 2.8 $\mathrm{ng} / \mathrm{g}$ of creatinine). No significant difference was observed between the GH-deficient subjects (group 2) and children with idiopathic growth failure (group 3).

Prepubertal and pubertal children in each of the three groups excreted similar amounts of urinary $\mathrm{GH}$ when the data were standardized for body weight, body surface area, and per $\mathrm{g}$ of creatinine excretion.

Twelve hypopituitary patients (group 2) excreted significantly greater amounts of urinary $\mathrm{GH}(0.41 \pm 0.07 \mathrm{ng} / \mathrm{kg})$ in the first $12 \mathrm{~h}$ after $\mathrm{GH}$ administration compared to the baseline period $(0.12 \pm 0.02 \mathrm{ng} / \mathrm{kg}, p<0.01)$.

Increased excretion of urine $\mathrm{GH}$ was observed in one partially treated acromegalic woman $(2.0 \mathrm{ng} / \mathrm{kg} / 12 \mathrm{~h})$; her plasma $\mathrm{GH}$ concentration was $46 \mathrm{ng} / \mathrm{ml}$.

\section{DISCUSSION}

After 1970 , interest in quantitating urinary $\mathrm{GH}$ waned because available assays lacked the sensitivity needed to measure the low concentrations of $\mathrm{GH}$ in urine. Also, the presence of low molecular weight molecules resulted in overestimation of urinary $\mathrm{GH}$ excretion (11). In 1972, Hanssen (13) demonstrated that prior dialysis of urine eliminated nonspecific interference from salts and urea. Hanssen (13) also lyophilized the specimen to yield a 50 -fold concentrate. These procedures improved the specificity and sensitivity of the $\mathrm{GH}$ assay. Quantitation of urinary $\mathrm{GH}$ was carried out on 18 adults; nine controls, three hypopituitary, and six acromegalic subjects. Two of the hypopituitary patients had values that fell below the sensitivity of his RIA $(0.39 \mathrm{ng} / \mathrm{ml})(13)$. 
Table 2. Urinary $G H$ excretion per $12 \mathrm{~h}$ standardized for body wt, body surface area, and urinary creatinine excretion $(\text { mean } \pm S E M)^{*}$

\begin{tabular}{|c|c|c|c|c|c|}
\hline \multicolumn{2}{|r|}{ Group } & \multirow{2}{*}{$\frac{n}{31}$} & \multirow{2}{*}{$\begin{array}{c}\begin{array}{c}\text { Mean GH } \\
(\mathrm{ng} / \mathrm{kg})\end{array} \\
0.27 \pm 0.02\end{array}$} & \multirow{2}{*}{$\begin{array}{c}\begin{array}{c}\text { Mean GH } \\
\left(\mathrm{ng} / \mathrm{m}^{2}\right)\end{array} \\
7.62 \pm 0.56\end{array}$} & \multirow{2}{*}{$\begin{array}{c}\begin{array}{c}\text { Mean GH } \\
\text { (ng/g creatinine) }\end{array} \\
43.2 \pm 6.9\end{array}$} \\
\hline 1 & Normal controls & & & & \\
\hline 2 & GH deficient & 21 & $0.08 \pm 0.02$ & $2.65 \pm 0.34$ & $23.7 \pm 3.8$ \\
\hline
\end{tabular}

* Significance: group 1 versus 2 or $3, p<0.01$ for all cases; group 2 versus $3, p<0.02 \mathrm{GH}(\mathrm{ng} / \mathrm{kg}), \mathrm{GH}\left(\mathrm{ng} / \mathrm{m}^{2}\right)$.

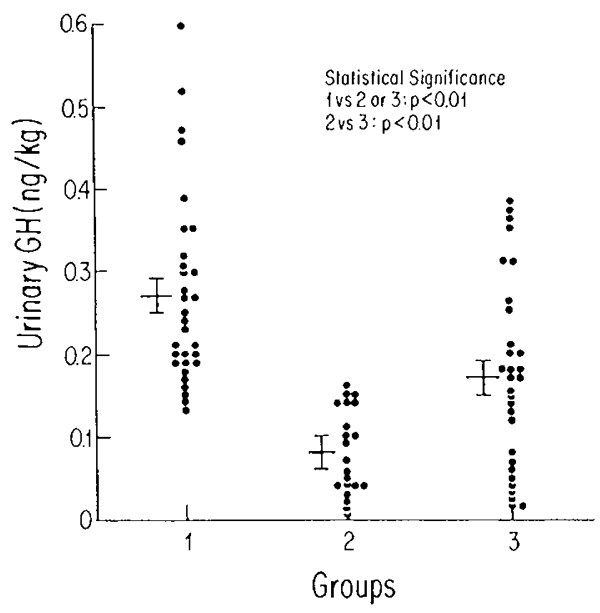

Fig. 2. Output of urinary GH in 12-h overnight urine collections obtained from healthy children (group 1), subjects with GH deficiency (group 2), children with idiopathic growth failure (group 3). Bars indicate the mean \pm SEM. Approximately one-quarter of the hypopituitary patients had values that overlapped with the control group.

For reasons cited previously, we set out to reevaluate the merits of measuring urinary $\mathrm{GH}$ excretion in children with normal and abnormal growth using a slight modification of the Hanssen procedure and an assay with improved sensitivity.

The authenticity of urinary $\mathrm{GH}$, molecular weight $22 \mathrm{kDa}$ was confirmed by HPLC in the present study. Similar conclusions about the molecular weight of urinary $\mathrm{GH}$ were reported by investigators who used polyacrylamide gel electrophoresis or Sephadex gel filtration $(13,16)$. We determined that the HPLC elution profile of urinary $\mathrm{GH}$ was identical to both biosynthetic and pituitary-derived GH standards. Furthermore, immunoreactivity of the HPLC fractions were assayed using a double monoclonal IRMA technique that recognizes only intact $\mathrm{GH}$ and the standard GH polyclonal assay (NHPP). The immunoreactive GH profiles defined by the two assays were identical.

The output of urinary GH in hypopituitary children given an injection of biosynthetic $\mathrm{GH}$ was significantly greater than the value observed before treatment. Less than $0.001 \%$ of administered biosynthetic $\mathrm{GH}$ was measured in urine collected from 12 of our hypopituitary children. Similar estimates have been reported previously (13).

In the large cohort of children who participated in our study, we observed that mean urinary GH excretion was significantly greater in control subjects compared to the children with either $\mathrm{GH}$ deficiency or idiopathic growth failure. This difference was observed irrespective of the parameters used to standardize the data. Some authors have standardized urinary output of GH on the basis of creatinine excretion to compensate for inaccuracy of urine collection $(17,18,19)$. However, previous reports have documented that protein synthesis and creatinine excretions are lower in hypopituitary children than in normal children $(20,21)$. Thus expressing renal output of GH per $g$ of urinary creatinine is likely to result in falsely high values. This may explain the lack of statistical difference between groups 2 and 3 when GH concentrations are expressed per $g$ of creatinine.
Approximately $50 \%$ of the children with idiopathic growth failure had urinary $\mathrm{GH}$ values that were similar to those of children with classical GH deficiency. It would appear that the group consisting of children with idiopathic growth failure is a heterogeneous population and that almost one-half of the children may have GH deficiency. The rest of the children in group 3 who had urinary GH values in the normal range may have a bioinactive $\mathrm{GH}$ molecule, unrecognized nutritional defects, or receptor problems. The overlap of individual urinary $\mathrm{GH}$ measurments among the groups resembles the spread of individual plasma GH concentrations determined by constant blood withdrawal (integrated $\mathrm{GH}$ concentration) or by serial blood sampling over $24 \mathrm{~h}$ in similar populations of children $(2-4,6)$. Less overlap of urinary $\mathrm{GH}$ values was observed between the normal and hypopituitary patients.

Based on the intergroup differences observed in this study and the reduced cost and discomfort of the test, it would appear that measurement of urinary $\mathrm{GH}$ may prove to be useful in screening patients with suspected $\mathrm{GH}$ deficiency or $\mathrm{GH}$ excess. Although this approach has inherent problems relative to accuracy of urine collection, it permits assessment of spontaneous output of $\mathrm{GH}$ over time in very small infants and children. During the course of our studies an even more sensitive assay for urinary GH was described by Hashida et al. (17) that uses a sandwich horseradish peroxidase enzyme fluorophotmetry technique; the sensitivity of the assay was increased to $0.03 \mathrm{ng} / \mathrm{ml}$. The range of values observed in our patients was similar to the range of urinary $\mathrm{GH}$ per $\mathrm{g}$ of creatinine reported by Hashida and coworkers in 37 healthy children $(18,19)$. Significantly lower output of urinary $\mathrm{GH}$ was found in five hypopituitary children (18).

We recently reported that quantitation of urinary Somatomedin C/IGF-I provides diagnostic information about patients with $\mathrm{GH}$ deficiency and $\mathrm{GH}$ excess $(22,23)$. Additional investigations are required in children with normal and abnormal growth to determine whether combined measurements of $\mathrm{GH}$ and Somatomedin $\mathrm{C} / \mathrm{IGF}-\mathrm{I}$ in urine will aid in recognizing specific defects in the pathway of GH secretion and action.

Acknowledgments. The authors are indebted to Irene Johnson, senior lab technician for technical assistance.

\section{REFERENCES}

1. Kowarski AA, Schneider J, Ben-Galim E, Weldon VV, Daughaday WH 1978 Growth failure with normal serum RIA-GH and low somatomedin activity: somatomedin restoration and growth acceleration after exogenous $\mathrm{GH}$. J Clin Endocrinol Metab 47:461-464

2. Spiliotis BE, August GP, Hung W, Sonis W, Mendelson W, Bercu BB 1984 Growth hormone neurosecretory dysfunction: a treatable cause of short stature. JAMA 251:2203-2230

3. Zadik Z, Chalew SA, Raiti S, Kowarski AA 1985 Do short children secrete insufficient quantities of growth hormone? Pediatrics 76:355-360

4. Bercu BB, Shulman D, Root AW, Spiliotis BE 1986 Growth hormone (GH) provocative testing frequently does not reflect endogenous $\mathrm{GH}$ secretion. J Clin Endocrinol Metab 63:709-716

5. Kowarski AA, Thompson RG, Migeon CJ, Blizzard RM 1971 Determination of integrated plasma concentrations and true secretion rates of human growth hormone. J Clin Endocrinol 32:356-360

6. Plotnick LP, Lee PA, Migeon CJ, Kowarski AA 1979 Comparison of physiological and pharmacological tests of growth hormone function in children with short stature. J Clin Endocrinol Metab 48:811-815

7. Geller J and Loh A 1963 Identification and measurement of growth hormone in extracts of human urine. J Clin Endocrinol Metab 23:1107-1114

8. Salinas A, Monckeberg F, and Beas F 1963 Immunological detection of growth 
hormone in normal human urine. Lancet 2:302-303

9. Franchimont P 1965 Dosage radio-immunologique de l'hormone de croissance dans les urines. Ann Endocrinol 26:627-631

10. Sakuma M, Irie M, Kaxou S, Tsushima T and Nakao K 1968 Measurement of urinary human growth hormone by radioimmunoassay. J Lab Clin Med 28:103-105

11. Girard J, Greenwood FC 1968 The absence of intact growth hormone in urine as judged by radioimmunoassay. $\mathrm{J}$ Endocrinol 40:493-503

12. Bala RM, Beck JC 1971 Human growth hormone in urine. J Clin Endocrinol Metab 33:799-806

13. Hanssen KF 1972 Immunoreactive growth hormone in human urine. Acta Endocrinol 71:665-676

14. Schalch DS, Parker ML 1964 A sensitive double antibody immunoassay for human growth hormone in plasma. Nature 203:1141-1145

15. Greenwood FG, Hunter W, Glover JS 1963 The preparation of I-131 labeled human growth hormone of high specific radioactivity. Biochem J 89:114123

16. Baumann G, Abramson EC 1983 Urinary growth hormone in man: evidence for multiple molecular forms. J Clin Endocrinol Metab 56:305-311

17. Hashida S, Ishikawa E, Nakagawa K, Ohtaki S, Ichioka T, Nakajima K 1985 Demonstration of human growth hormone in normal urine by a highly specific and sensitive sandwich enzyme immunoassay. Ann Lett 18:16231634

18. Hashida S, Ishikawa E, Nakagawa K, Ohtaki S, Shigenaga H, Hayakawa K, Mohri Z, Murakami Y, Ichioka T, Nakajima K 1986 Level of human growth hormone $(\mathrm{HGH})$ in urine determined by a highly specific and sensitive sandwich enzyme immunoassay. Ann Lett 19:625-638

19. Ishikawa E, Hashida S, Kato Y, Imura H 1987 Sensitive enzyme immunoassay of human growth hormone for clinical applications: review. J Clin Lab Anal $1: 238-242$

20. Ballard FJ, Burgogyne JL, Thomase FM, Penfold JL 1983 Growth hormone induced changes in myofibrillar protein breakdown in hypopituitary children. Clin Sci 64:315-320

21. Richter I, Heine W, Plath C, Mix M, Wutzke KD, Towe J 198715 N Tracer techniques for the differential diagnosis of dwarfism and prediction of growth hormone action in children. J Clin Endocrinol Metab 65:74-77

22. Quattrin T, Albini C, MacGillivary M 1987 Quantitation of urinary somatomatomedin C (Sm-C/IGF-I). 56th Annual Meeting of the Society for Pediatric Research Anaheim, CA, p 252(abstr)

23. Quattrin T, Albini C, Vandlen R, MacGillivary MH Quantitation of urinary somatomedin $\mathrm{C}(\mathrm{Sm}-\mathrm{C} / \mathrm{IGF}-\mathrm{I})$ in children with normal and abnormal growth. J Clin Endocrinol Metab 65:1168-1171 